\begin{tabular}{ccc}
\hline & International Journal of Engineering \&Technology, $7(3.12)(2018) 955-959$ \\
SPC & International Journal of Engineering \& Technology \\
Website www.sciencepubco.com/index.php/IJET & Research paper \\
\hline
\end{tabular}

\title{
An Experimental Study on Structural Behavior of Lathe Waste in Conventional and Self-Compacting Concrete
}

\author{
Aluri Bhavana ${ }^{1 *}$, M. L. Sai Rangarao ${ }^{2}$ \\ ${ }^{1}$ P.G Student, Koneru Lakshmaiah Education Foundation, Vaddeswaram, Guntur, AP, India \\ ${ }^{2}$ Assistant Professor, Koneru Lakshmaiah Education Foundation, Vaddeswaram, Guntur, AP, India \\ *Corresponding Author Email: ' aluribhavana94@gmail.com
}

\begin{abstract}
To diminish the effect on condition and impact of soil disintegration the lathe waste or steel scrap i.e. machine squander, which is acquired from mechanical machines, can be utilized as reusing material in the concrete blend. This project emphasizes the study on selfcompacting concrete (SCC) and conventional concrete (CC) with the addition of machine squander. The investigation is done with and without the addition of steel scrap in conventional and self-compacting concrete. The optimal content of steel scrap is utilized out of $1 \%$, $2 \%$, and $3 \%$. Multiple trail mixes were carried out to find out the optimal content of steel scrap. The fresh and hardened properties of concrete are resolved. The test completed determining flow properties of SCC are Slump, L-box, V-funnel tests. The flexural, compressive and split tensile strengths of concrete were resolved. A total 8 beam specimens were cast and tested under simply supported condition. Deformational behavior was compared between conventional concrete, beam specimens to SCC concrete beam specimens.
\end{abstract}

Keywords: bending, deformational behavior, simply supported beam, shear, steel scrap.

\section{Introduction}

Prior self-compacting (SCC) concrete was a strategy took after by utilizing the tremie mechanical apparatus without vibration, which is done by the position of concrete submerged, which brings about lower strength and quality conflicting. So as to accomplish legitimate consistency and quality the self-compacting concrete is to be centered on high-performance concrete. SCC is first created by Japan researcher OKUMARA.

According to EFNARC specifications and guidelines are given, the framework is designed and implementation of SCC is done from the year 2001. Self-compacting concrete (SCC) plays a significant role in the present day construction industry. SCC is more advantageous when compared to conventional concrete. In the areas or section of congested reinforcement where heavy compaction is required, SCC is more strategic as it can flow on its own weight without using mechanical vibrators which causes the reduction in power consumption and utilization of drudge. SCC exhibits awesome deformability and excellent segregation resistance.

In the case of conventional concrete the major problem arises with compaction process at the thinner section and at the areas of congested reinforcement which may lead to the durability problems. The insufficient mixture of concrete and improper compaction at corners leads to the formation of entrapped voids and decrease in strength of concrete. As the SCC is designed to consolidate on its own mass the complexion can be denied. According to the specifications and design method are given by EFNARC in the year 2001 the SCC mix deigned is carried out. The mix quantities were calculated and through the number of trails mixes the were done using the VMA and with the use super plasticisers. In the present project, only auromix 300 plus is used.
The slump flow test is performed to measure the flowing ability and to check out the segregation resistance of concrete, tests such as L-box test, V-funnel test, U-box tests are executed. The admixture is used as per the dosage to attain the required slump flow. The hardened concrete properties such as flexural strength, compressive strength, split tensile strength, deflection of RC beams were studied and reported as results acquired.

Variety of lathe scrape is obtained during the manufacturing process of the different variety of shafts. The manufacturing shafts are of the different variety of material such as cast iron, iron, stainless steel.The machine tool called lathe which can be primarily utilized not only for shaping metal article but also for wood or other materials. The metal piece is inserted into the lathe which enables the piece to be held and rotated, while the tool bit is allowed to the action for cutting.The designed elemental lathe was idolized to prepare crankshafts, knurled surfaces, drilled holes, tampered work and screw threads. This obtained dispose of lathe waste material accounts for environmental corruption. Now a days the majority of the countries are undergoing the problem of landfill. Landfilling is a tedious job because of large amount discharge of waste products are from the evolution of massproduction and construction. Such discharged waste material was not properly redeemed. In order to promote a worthwhile reduction in the affliction of soil, the technique of redemption should be implemented effectively.

\section{Materials}

\subsection{Lathe waste}

The waste which is obtained from mechanical lathe machines is collected and used as recycling material the mixture of concrete. The lathe waste is used in the conventional and SCC concrete 
mixtures. As the aspect ratio was not constant, it varies from 50 to 110 for manually produced lathe waste. The length and thickness of lathe waste vary from $15 \mathrm{~mm}$ to $50 \mathrm{~mm}$ and 0.45 to $1 \mathrm{~mm}$. The amount of lathe waste used is about $1 \%, 2 \%, 3 \%$ in the concrete mixture. The optimum percentage of lathe waste is obtained from compressive strength of concrete.

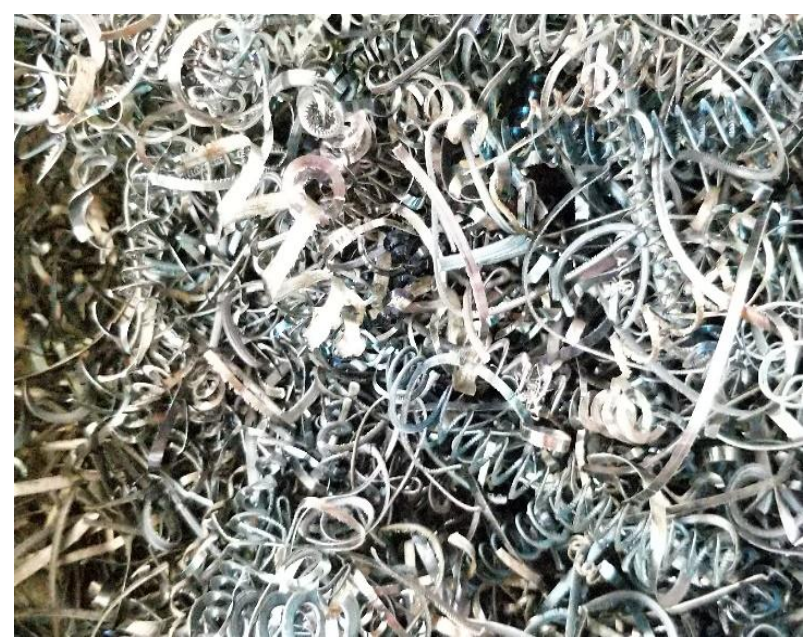

Fig. 1: Lathe waste

\subsection{Cement}

Ordinary portland cement of grade 53 according to IS:12269-2013 was utilized.

\subsection{Fine Aggregates}

Fine aggregates used is of manufacturing and which is passing through $4.75 \mathrm{~mm}$ IS sieve of zone-II. Grading of the zone is known by performing sieve analysis. As per IS 383-1970 the properties such as Specific gravity- 2.55, Fineness modulus- 2.72, Bulk density (loose)- $15.86 \mathrm{kN} / \mathrm{m}^{3}$, Bulk density (density)- 16.89 $\mathrm{kN} / \mathrm{m}^{3}$.

\subsection{Coarse Aggregates}

The aggregates utilized are of particle size which is less than 10$12 \mathrm{~mm}$ are used for SCC concrete. Size of aggregates used for nominal concrete is the combination of $20 \mathrm{~mm}$ and $10-12 \mathrm{~mm}$ Specific gravity-2.8, Fineness modulus-7.26, Bulk density (loose)$14.7 \mathrm{kN} / \mathrm{m}^{3}$, Bulk density (dense) $-15.3 \mathrm{kN} / \mathrm{m}^{3}$.

\subsection{Water}

Water which used during cast and curing process should be free from chemicals. Versatile water accessible from research facility which fulfills the drinking standard was utilized for blending also, curing.

\subsection{Super Plasticiser}

Super plasticiser utilized was Auramix 300 plus which is produced to satisfy the requirement for concrete with long workability maintenance for more than four hours.

\section{Experimental Procedure}

\subsection{Mix Design}

Mix design was carried out for M30 grade concrete according to IS:10262-2009.The mix proportions of concrete were 1:2.3:2.3:0.4 and Water content was about 158 liters for SCC concrete. Mix proportions for conventional concrete were 1:1.8:2.3:0.5.
Table 1: Mix proportion of conventional concrete

\begin{tabular}{ccc}
\hline S.No & Materials & $\begin{array}{c}\text { Mix quantities per } \mathbf{~ m}^{\mathbf{3}} \text { of } \\
\text { concrete }\end{array}$ \\
\hline 1 & Cement & $394 \mathrm{~kg} / \mathrm{m}^{3}$ \\
2 & Fine aggregates & $705.12 \mathrm{~kg} / \mathrm{m}^{3}$ \\
3 & Coarse aggregates & $1139.84 \mathrm{~kg} / \mathrm{m}^{3}$ \\
4 & Water & $197 \mathrm{~L} / \mathrm{m}^{3}$ \\
\hline
\end{tabular}

Table 2: Mix proportion of SCC concrete

\begin{tabular}{ccc}
\hline S.No & Materials & $\begin{array}{c}\text { Mix quantities per } \mathbf{m}^{\mathbf{3}} \text { of } \\
\text { concrete }\end{array}$ \\
\hline 1 & Cement & $400 \mathrm{~kg} / \mathrm{m}^{3}$ \\
2 & Fine aggregates & $922.5 \mathrm{~kg} / \mathrm{m}^{3}$ \\
3 & Coarse aggregates & $922.5 \mathrm{~kg} / \mathrm{m}^{3}$ \\
4 & Water & $158 \mathrm{~L} / \mathrm{m}^{3}$ \\
\hline
\end{tabular}

\subsection{Detailing of Specimens}

Specimens were cast according to the mix quantities obtained from mix design. Through the number of trail mixes, required tests for SCC concrete were conducted to attain optimum mix. To the total weight of concrete steel, scrap was included around 1\%, $2 \%$, and $3 \%$. A total of 30 Cubes, 15 cylinders, and 8 PCC beams were cast with standard dimensions respectively. Total 4 nominal concrete and 4 SCC beam specimens were cast choosing $2 \%$ optimum of steel scrap. The dimensions of RCC beams are $1500 \mathrm{mmX} 230 \mathrm{mmX} 230 \mathrm{~mm}$ respectively. The cast specimens were cured for 28 days.
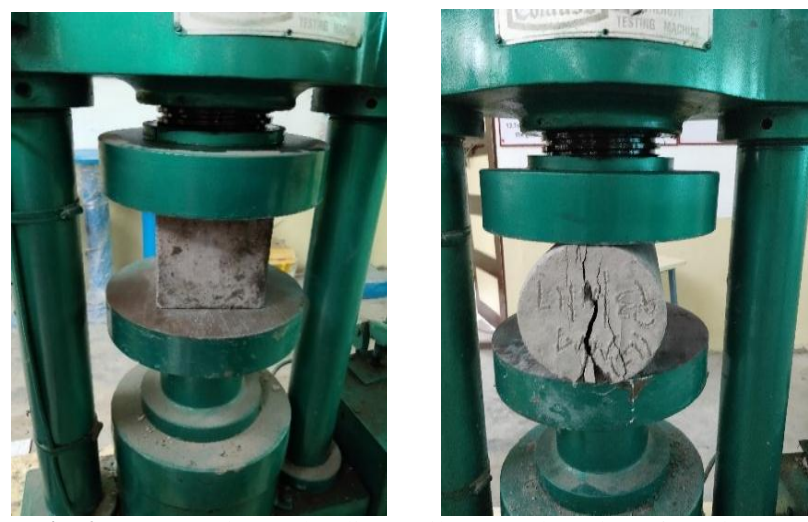

Fig. 2: Compression and Split Tensile strength testing of specimens

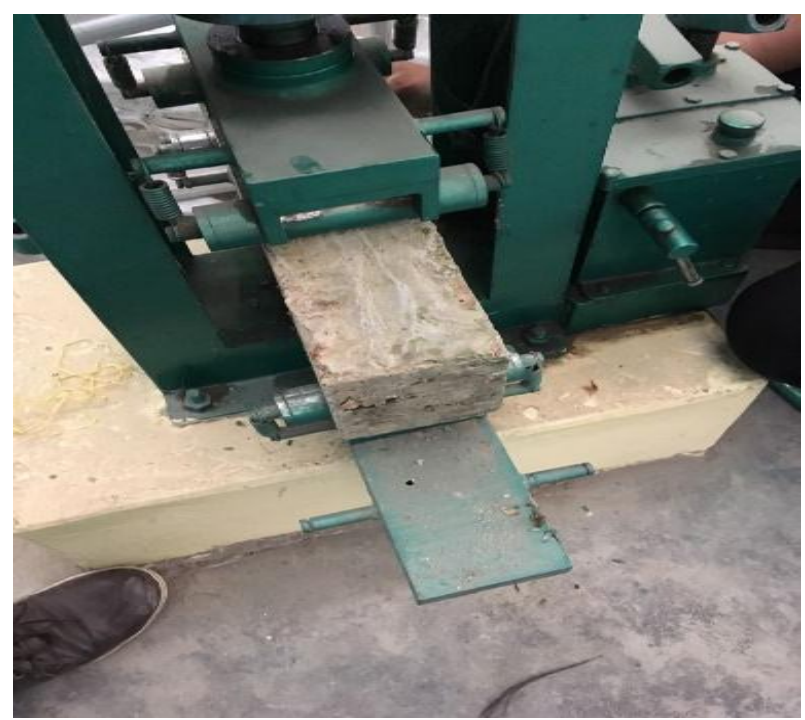

Fig. 3: Flexural testing of PCC beam specimens

\subsection{Testing Setup}

After 28 days the specimens were prepared for testing. Compressive and split tensile strength test was accompanied by cubes and cylinders are shown in the figure. All the RC beam 
specimens were simply supported and tested under pure bending case. The loading frame can deliver a maximum load of 200 tonnes. Among $8 \mathrm{RC}$ beam specimens, 4 specimens were nominal concrete and other 4 were SCC specimens. Under nominal and SCC concrete 2 of them are control specimens and in other 2 specimens lathe waste was added. Finally, the Beam specimens were tested under pure bending case. The specimen detailing was shown in the figure (4)

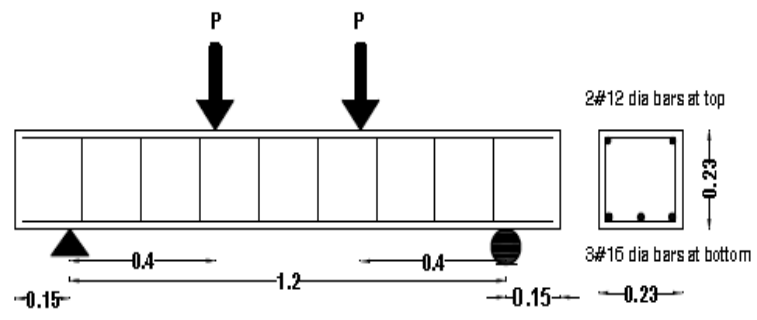

Fig. 4: The test set up for beam specimens

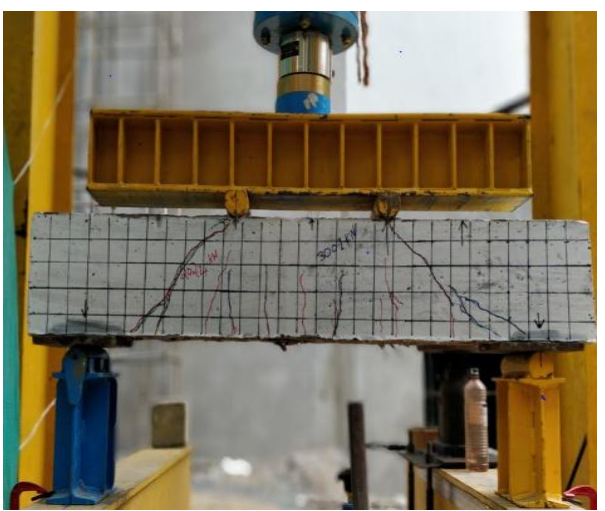

Fig. 5: Test specimen of nominal mix in conventional concrete

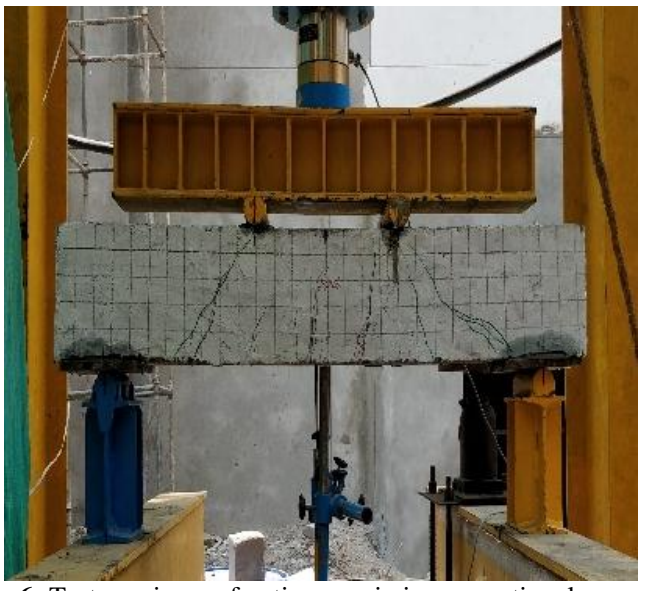

Fig. 6: Test specimen of optimum mix in conventional concrete

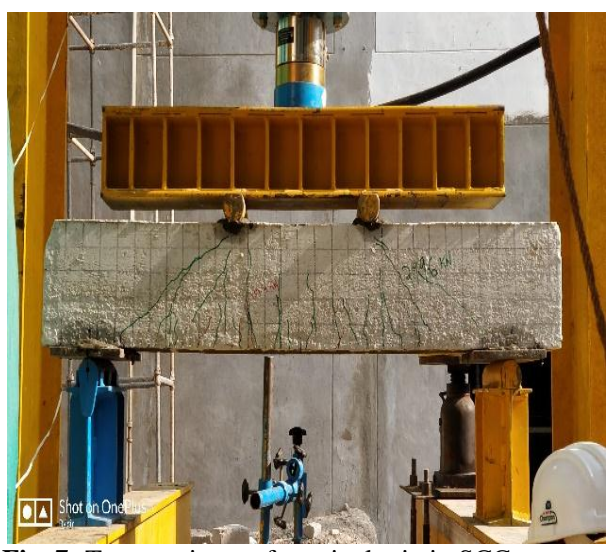

Fig. 7: Test specimen of nominal mix in SCC concrete

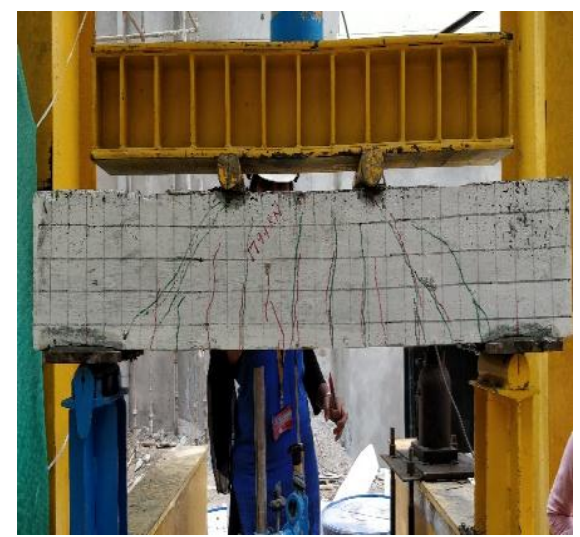

Fig. 8: Test specimen of optimal mix in SCC concrete

\section{Results and Discussion}

Demonstrating the results of fresh and hardened properties of concrete.

\subsection{Fresh Concrete properties for SCC}

Table 3: Typical range of SCC mix composition by EFNARC

\begin{tabular}{cccc}
\hline Tests conducted & $\begin{array}{c}\text { Normal } \\
\text { SCC mix }\end{array}$ & $\begin{array}{c}\text { Optimal } \\
\text { SCC mix }\end{array}$ & $\begin{array}{c}\text { Typical ranges } \\
\text { for the tests }\end{array}$ \\
\hline Slump flow test & 580 & 610 & $550-650$ \\
T50 & $5 \mathrm{sec}$ & $9 \mathrm{sec}$ & $3-5 \mathrm{sec}$ \\
V-funnel & $9 \mathrm{sec}$ & $12 \mathrm{sec}$ & $6-12 \mathrm{sec}$ \\
L-box test (h2/h1) & 0.93 & 0.85 & $0.8-1.0$ \\
& $\mathrm{~mm}$ & $\mathrm{~mm}$ & $\mathrm{~mm}$ \\
\hline
\end{tabular}

For normal and optimal SCC mix the workability was found to be in its typical range. In the instance of optimal SCC mix as lathe waste is added, there is a considerable increase in the amount of admixture to achieve workability.

\subsection{Hardened Concrete Properties}

Hardened concrete properties such as compressive, split tensile and flexural strength tests of cubes, cylinder and PCC beams results were given below.

\subsubsection{Compressive Strength Test Results}

Table 4: Compressive strength results for conventional concrete

\begin{tabular}{ccc}
\hline Conventional concrete & 7days MPa & 28 days MPa \\
\hline $0 \%$ & 31.5 & 37.3 \\
$1 \%$ & 32.9 & 35.5 \\
$2 \%$ & 34.3 & 41.5 \\
$3 \%$ & 33.8 & 38.88 \\
\hline
\end{tabular}

Compared to nominal concrete there observed increase of compressive strength in SCC concrete. In conventional concrete the compressive strength in optimal mix is more than the control mix. At $2 \%$ optimum of lathe waste there observed $8.8 \%$ increase of 7 day compressive strength and $11.6 \%$ for 28 days in optimal mix than in control mix.

Table 5: Compressive strength results for SCC concrete

\begin{tabular}{ccc}
\hline $\begin{array}{c}\text { Lathewaste content in } \\
\text { SCC }\end{array}$ & $\mathbf{7}$ days $\mathbf{M P a}$ & 28 days MPa \\
\hline $0 \%$ & 37.25 & 39.25 \\
$1 \%$ & 36.25 & 40.4 \\
$2 \%$ & 41.1 & 44.3 \\
$3 \%$ & 34.5 & 42.4 \\
\hline
\end{tabular}

In self-compacting concrete the compressive strength in optimal SCC mix is more than the control SCC mix. At $2 \%$ optimum of lathe waste there observed $10.3 \%$ increase of 7 day compressive strength and $12.8 \%$ for 28 days in optimal SCC mix than in control SCC mix. 


\subsubsection{Split Tensile Strength Test Results}

Table 6: Split tensile strength results for conventional concrete

\begin{tabular}{cc}
\hline Conventional concrete & 28 days MPa \\
\hline $0 \%$ & 2.4 \\
$1 \%$ & 2.5 \\
$2 \%$ & 3.0 \\
$3 \%$ & 2.8 \\
\hline
\end{tabular}

Increase of split tensile strength has been observed than in control mix. At $2 \%$ optimum of lathe waste there observed $16.6 \%$ increase split tensile strength for 28 days in optimal mix than in control mix

Table 7: Split tensile strength results for SCC concrete

\begin{tabular}{cc}
\hline SCC concrete & 28 days MPa \\
\hline $0 \%$ & 2.9 \\
$1 \%$ & 3.2 \\
$2 \%$ & 3.4 \\
$3 \%$ & 3.0 \\
\hline
\end{tabular}

Increase of split tensile strength has been observed than in contro SCC mix. At $2 \%$ optimum of lathe waste there observed $20.6 \%$ increase split tensile strength for 28 days in optimal mix than in control mix.

\subsubsection{Flexural Strength Test Results for PCC Beam}

Table 8: Flexural strength results for conventional and SCC concrete

\begin{tabular}{ccc}
\hline & $\begin{array}{c}\text { Conventional concrete } \\
\mathbf{2 8} \text { days } \mathbf{M P a}\end{array}$ & $\begin{array}{c}\text { SCC concrete 28 days } \\
\text { MPa }\end{array}$ \\
\hline $0 \%$ & 5.7 & 5.9 \\
$2 \%$ & 6.4 & 6.8 \\
\hline
\end{tabular}

Pcc beams flexural strength has been increased by $12 \%$ in conventinal concrete and $15.5 \%$ in SCC concrete for 28 days

\subsection{Testing on RC Beam Specimen}

In the illustration of RC beams, specimens were tested under pure bending case. The graphs given below demonstrates the increase of ultimate strength, Deformational behavior and stress-strain behavior of nominal mix and optimal mix of conventional (CC) and self-compacting concrete (SC) were being compared.

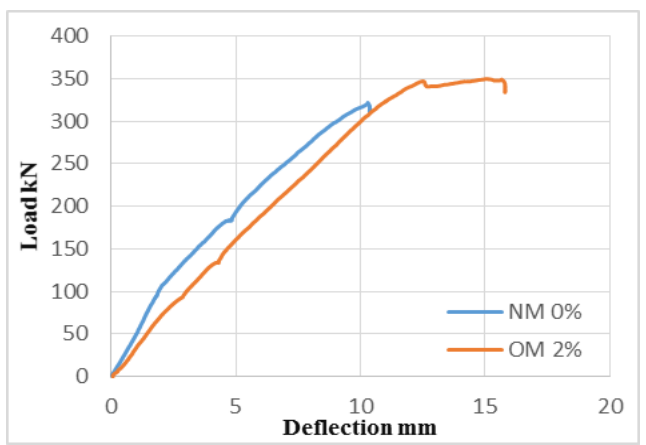

Fig. 5: Load- deflection graph for nominal and optimal mix in conventional concrete

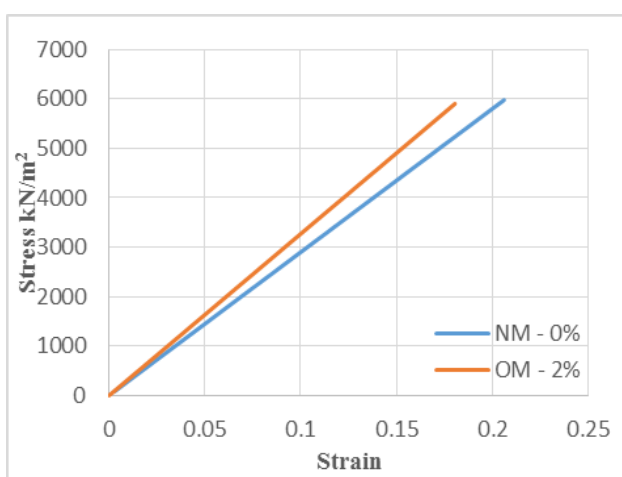

Fig. 5: Stress-strain graph for nominal and optimal mix in conventional concrete

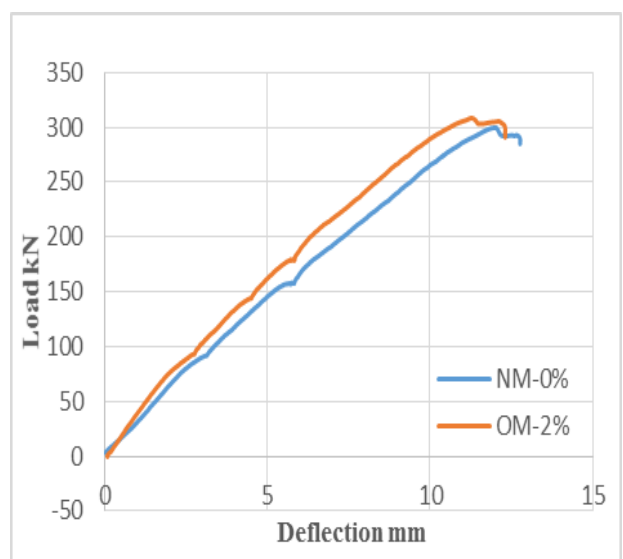

Fig. 6: Load-deflection graph for nominal and optimal mix in SCC concrete

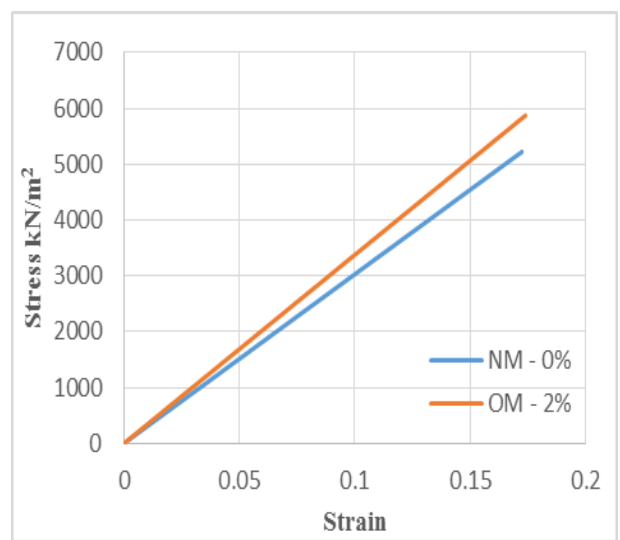

Fig. 7: Stress-strain graph for nominal and optimal mix in SCC concrete

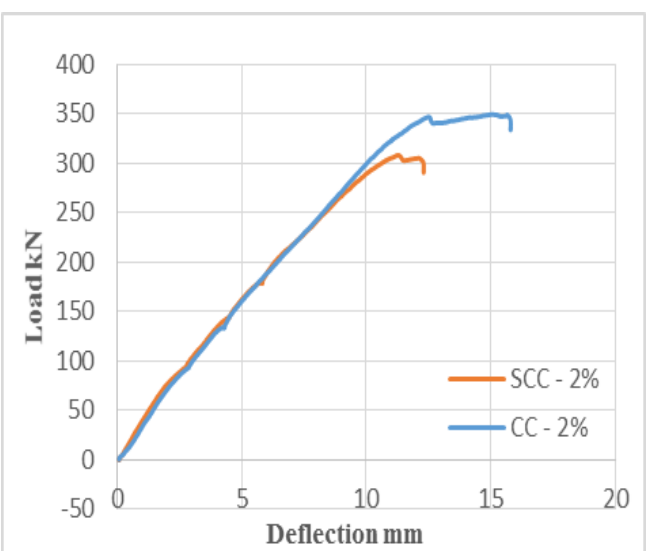

Fig. 8: Load-deflection graph for $2 \%$ optimum in conventional and SCC concrete

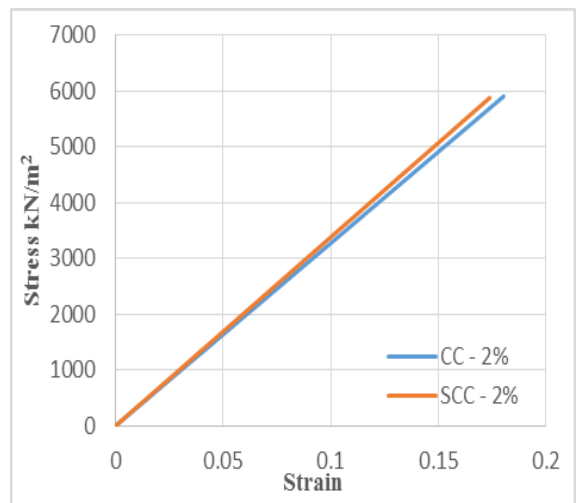

Fig. 9: Stress-strain graph for $2 \%$ optimum in conventional and SCC concrete 


\section{Conclusions}

In view of the exploratory examinations conveyed out the accompanying conclusions were drawn.

- The optimum lathe waste or steel scrap content was found to be $2 \%$.

- Compressive, split tensile and flexural strengths were greater than conventional concrete.

- Conferring to IS 456: 2000, design benchmarks of conventional and SCC beams, the major failure was diagonal cracking and the cracks were developed from the support in the direction of loading point.

- Ultimate stress has been developed on the point of application of ultimate load.

- Failure and crack pattern were dissimilar for both conventional and SCC concrete.

- Corresponding stress-strain values were calculated by the area, young's modulus of the specimens.

- Applied load on beam specimens was $25 \%$ more than the load designed in CC and SCC aspects.

- Lathe waste is much more effective in optimal mix of conventinal concrete than in self-compacting concrete.

\section{Acknowledgement}

I wish to convey my sincere gratitude to M.L. Sai Rangarao sir for his excellent guidence, encouragement and support during the course of my work from last one year. I truly appreciate and values his thoughtful knowledge esteemed supervision and encourage-ment from beginning to end the of project completion Special thanks to Friends and laboratoty technicians of Koneru Lakshmaih Educational Foundation for their tremendous support .

\section{References}

[1] G. Vijayakumar, P. Senthilnathan, K. Pandurangan and G. Ramakrishna, (2012), "Impact and Energy Absorption Characteristics of Lathe Scrap", International Journal of Structural and Civil engineering research", Vol. 1, No. 1, pp. 1-6.

[2] S. Meenakshi Sudarvizhi, M. Rohini Shanmugapriya, and R. Ilangovan, (2013), "An experimental investigation on mechanical properties of concrete using industry waste", International Journal of Earth Science and Engineering., Vol. 6, No. 2, pp. 118-122.

[3] M. Kumaran, M. Nithi and K. R. Reshma, (2015), "Effect of lathe waste in concrete as reinforcement", Special Issue International Conference on Technological Advancements in Structures and Concstruction, pp. 78-83.

[4] J. Joy and R. Rajeev, "Performance of Steel Scrap in Concrete (2015)", International Journal for Scientific Research and Development, Vol. 2, No. 12, pp. 755-758.

[5] P. Haldkar and A. Salunke, (2016), "Analysis of Effect of Addition of Lathe Scrap on the Mechanical Properties of Concrete", International Journal of Science and research, Vol. 5, No. 4, pp. 23212325 .

[6] T. Anand, M. Balaji and S.Vijaya Baskar, (2017 ), "An Experimental Investigation On Rheological Properties Of SCC Using Steel Scrap", International Journal of Civil Engineering, pp. 125128

[7] M. Shaikh and A. Patil, (2016), "Study on Addition of Lathe Scrap to Improve the Mechanical Properties of Concrete", International journal of Innovative Research in Science Engineering and Technology, Vol. 5, pp. 8573-8578.

[8] Rahman, S. M. Ali, and S. Azeemuddin, (2017), "Performance Analysis of Steel Scrap in Structural Concrete", International Journal of Mechanical and Civil Engineering, Vol. 14, No. 2, pp. 42-47.

[9] M. S. Shetty, (2005)"Concrete technology: theory and practice". S Chand,

[10] B. of Indian Standards, "IS 456 (2000): Plain and Reinforced Concrete - Code of Practice.'

[11] N. (Narayanan) Subramanian, Design of reinforced concrete structures.
[12] DR. B. Krishna Rao, J. Rajesh, (2015), "A Study on Partial Replacement of Cement by Copper Slag in Self-Compacting Copper", International Journal of Science and Research, Vol. 5, No. 12, pp1824-1828. 